Отримано: 09 квітня 2018 р.

Прорецеензовано: 16 квітня 2018 р.

Прийнято до друку: 03 травня 2018 р.

e-mail: my-helena@ukr.net
Стащук О. В. Індикаторний підхід в оцінюванні стану фінансової безпеки акціонерних товариств. Наукові записки Начіонального університету «Острозька академія». Серія «Економіка» : науковий журнал. Острог : Вид-во НаУОА, червень 2018. № 9(37). C. $168-173$.

\title{
ІНДИКАТОРНИЙ ПІДХІД В ОЦІНЮВАННІ СТАНУ ФІНАНСОВОЇ БЕЗПЕКИ АКЦІОНЕРНИХ ТОВАРИСТВ
}

У статті досліджено особливості використання індикаторного підходу у процесі оиінювання стану фінансової безпеки корпоративних структур. Проведено критичний аналіз наявних поглядів науковців на виокремлення найбільи релевантних індикаторів для оиінки стану фінансової безпеки акціонерних товариств. Автором визначено основні переваги та недоліки індикаторного підходу оиінки стану фінансової безпеки акціонерних товариств $i$ запропоновано власне компонування таких показників.

Ключові слова: індикаторний підхід, показники оцінки, фінансова безпека, акціонерні товариства, науково-методичний підхід.

\author{
Стащук Елена Владимировна, \\ кандидат экономических наук, дочент кафедры финансов и кредита, \\ Восточноевропейский университет имени Леси Украинки

\section{ИНДИКАТОРНЫЙ ПОДХОД В ОЦЕНКЕ СОСТОЯНИЯ ФИНАНСОВОЙ БЕЗОПАСНОСТИ АКЦИОНЕРНЫХ ОБЩЕСТВ}

В статье исследованы особенности использования индикаторного подхода в процессе оценки состояния финансовой безопасности корпоративных структур. Проведен критический анализ существуюших взглядов ученых на выделение наиболее релевантных индикаторов для оценки состояния финансовой безопасности акиионерных обществ. Автором определены основные преимущества и недостатки индикаторного подхода оценки состояния финансовой безопасности акциионерных обществ и предложено собственное компоновки таких показателей.

Ключевые слова: индикаторный подход, показатели оченки, финансовая безопасность, акционерные общества, научно-методический подход.

\author{
Olena Stashchuk, \\ Ph.D. in Economics, Associate Professor at the Department of Finance and Credit, \\ Eastern European National University named after Lesya Ukrainka
}

\section{INDICATOR APPROACH TO ASSESSING THE STATE OF JOINT STOCK COMPANIES FINANCIAL SAFETY}

In the article the peculiarities of the indicator approach in the process of assessing the corporate structures financial security are explored. A critical analysis of the existing scientific attitudes to the identification of the most relevant indicators of the joint stock companies'financial security assessing has been carried out. The author identifies the main advantages and disadvantages of the indicator approach for assessing joint stock companies'financial security and proposes the proper layout of such indicators.

Key words: indicator approach, evaluation indicators, financial security, joint-stock companies, scientific and methodical approach.

Постановка проблеми. Динамізм умов функціонування акціонерних товариств зумовлює необхідність посилення подальших досліджень із проблематики оцінювання стану їх фінансової безпеки 3 метою отримання можливостей розробки адекватної фінансової політики та стратегії розвитку суб'єктів підприємницької діяльності. Фінансова безпека підприємницьких структур часто асоціюється із здатністю найефективніше використовувати фінансові ресурси для задоволення потреб, для чого оцінювання їі стану пропонують здійснювати на основі індикаторного методу.

Аналіз останніх досліджень і публікацій. Яскравими прихильниками використання такого теоретико-методичного підходу до оцінювання стану фінансової безпеки є О. А. Ареф’єва, О. І. Барановський, 
О. Р. Гладченко, Л. Гнилицька, Л. П. Гомілко, К. С. Горячева, Н. С. Зарубинська, В. М. Зарубинський, Н. П. Карачина, О. Кириченко, Ю. Кім, М. І. Копитко, І. Кудря, Т. Б. Кузенко, Р. С. Папєхін, О. М. Підхомний, Т. О. Тєльна, Т. В. Шлемко та інші.

Метою нашої статті є огляд особливостей сучасних поглядів науковців на використання індикаторного підходу в оцінюванні стану фінансової безпеки, а також формуванні висновків про доцільність їх імплементації у практику оцінювання стану фінансової безпеки корпоративних структур. Відповідно до поставленої мети в роботі запропоновано виконати такі завдання:

- провести критичний огляд поглядів учених на виокремлення індикаторів оцінювання стану фінансової безпеки суб'єктів господарювання;

- виявити переваги та недоліки застосування індикаторного методу оцінювання стану фінансової безпеки акціонерних товариств.

Виклад основного матеріалу. Найбільш поширеним у практиці фінансового менеджменту $є$ індикаторний підхід до оцінювання стану фінансової безпеки підприємства. Відповідно до такого методу, стан фінансової безпеки акціонерних товариств повинен визначатися шляхом обчислення окремих індикаторів і їх порівняння надалі із пороговими, нормальними (середніми) або критичними значеннями. В. О. Косевцов та I. Ф. Бінько вважають, що певний рівень безпеки має характеризуватися зіставленням фактичного значення конкретного показника на визначену дату з відповідним значенням затвердженого індикатора [1, с. 41]. У своїх дослідженнях Т. В. Шлемко проводить узагальнювальну оцінку стану фінансово-економічної безпеки підприємства на основі порівняння граничних і фактичних значень обраних індикаторів і формалізовано відображають це так [2, с. 68]:

$$
x_{i}=\left(\frac{P_{i \phi}}{P_{i H}}\right)^{b}
$$

де $P_{i \phi}, P_{i н}$ - фактичні та нормативні значення відібраного індикатора відповідно; $\mathrm{b}$ - показник ступеня.

Науковці також пропонують за баз порівняння (нормативний показник) обирати одне із таких значень: показник того підприємства, що має один регіон розташування; показники еталонних підприємств у галузі; показники підприємств-аналогів, розміщених за кордоном тощо [2, с. 70]. На нашу думку, така методика $\epsilon$ узагальнювальною, не відображає особливостей фінансової діяльності окремих типів підприємницьких структур, не враховує галузі їхньої діяльності, а також не передбачає критерію відбору показників до системи оцінювання стану фінансової безпеки акціонерних товариств. Водночас труднощі можуть виникнути й у процесі порівняння фактичних і порогових показників, оскільки надзвичайно складно віднайти таке підприємство за кордоном, яке б погодилося стати еталонним для досліджуваного вітчизняного підприємства. Окрім цього, рівень розвитку зарубіжних суб'єктів господарювання є значно вищим, а тому не зовсім доцільно порівнювати підприємства, що тривалий час функціонують у добре розвинутому ринковому середовищі із тими, де ринкова економіка знаходиться на стадії трансформації. Водночас, вважаємо, що такій методиці не вистачає стандартизованого набору індикаторів та надання їм граничних значень із метою здійснення адекватного порівняння фактично отриманих результатів розрахунків за кожним досліджуваним підприємством.

Своєю чергою, авторський доробок Г. В. Козаченка та В. П. Пономарьова містить пропозиції щодо застосування з метою оцінювання стану фінансової безпеки суб'єктів господарювання показник співвідношення обсягу брутто-інвестицій підприємства й обсягу його інвестиційних ресурсів, який необхідний для підтримання умов забезпечення їх фінансової безпеки. Методика розрахунку такого індикатора $\epsilon$ такою [3, с. 165]:

$$
P_{\phi Б \Pi !}=\frac{5 I^{t}}{I_{\Phi Б \Pi}^{t}}
$$

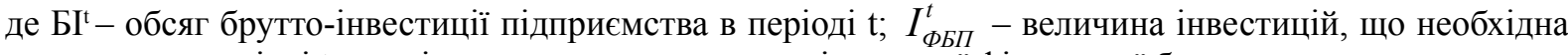
підприємству у періоді $t$ для підтримання достатнього рівня своєї фінансової безпеки.

Науковці також пропонують виокремлювати такі рівні фінансової безпеки суб’єкта підприємницької діяльності і за підсумками обчислення вище зазначеного індикатора: 1) підтримуючий рівень, за якого індикатор інвестицій знаходиться в межах до 0,05 одиниць; 2) мінімальний рівень, при якому індикатор інвестицій міститься в діапазоні від 0,06 до 0,1 одиниць; 3) дуже низький рівень, якому відповідає індикатор інвестицій у межах від 0,11 до 0,19 одиниць; 4) низький рівень фінансової безпеки підприємства, якій характерний показник інвестицій від 0,2 до 0,29 одиниць; 5) середній рівень, за якого розрахунковий показник інвестицій становить від 0,3 до 0,49 одиниць; 6) високий рівень фінансової безпеки, якому характерний показник інвестицій у межах від 0,5 до 0,7 одиниць; 7) дуже високий рівень - фактичне значення індикатора інвестування перевищує позначку в 0,7 одиниць [3, с. 167]. 
Вважаємо, що застосування саме показника інвестиційної діяльності до оцінювання стану фінансової безпеки підприємства $\epsilon$, безперечно, позитивним моментом, оскільки він $\epsilon$ індикатором розвитку самого суб'єкта господарювання. Проте така методика викликає певні сумніви щодо отримання адекватних результатів оцінювання стану фінансової безпеки як акціонерних товариств, так і підприємств інших організаційно-правових форм господарювання, оскільки визначити стан фінансової безпеки (підхід до оцінки якого повинен бути комплексним і системним) на основі лише одного індикатора $є$ необгрунтованим. Незрозумілим нам $є$ також показник інвестицій, що необхідна суб'єкту господарювання в періоді $\mathrm{t}$ для підтримання достатнього рівня своєї фінансової безпеки та методика його розрахунку, оскільки кожне інше підприємство має свої потреби в обсягах інвестицій. Окрім цього, якщо такий індикатор повинен відповідати достатньому рівню фінансової безпеки суб'єкта господарювання, тоді постає питання з якою метою нам необхідно розрахувати ще один індикатор стану фінансової безпеки шляхом порівняння брутто-інвестицій та обсягу інвестицій із достатнім рівнем фінансової безпеки підприємства. Тому вважаємо, що використання такої методики для оцінювання стану фінансової безпеки акціонерних товариств $є$ недоцільною.

Н. П. Карачина стверджує, що з метою виявлення стану фінансово-економічної безпеки суб'єкта господарювання та стану захисту його від загроз необхідно скористатися такими індикаторами: коефіцієнт зносу основних засобів, індекс зміни чисельності працівників, коефіцієнт покриття, індекс зміни чистого доходу від реалізації, чистий прибуток [4, с. 63-65].

Н. С. Зарубинська та В. М. Зарубинський у своїх дослідженнях виокремлюють такий набір показників оцінювання фінансової безпеки суб'єктів господарювання: коефіцієнт ліквідності, швидкість ліквідності оборотних активів, швидкість обороту товарних запасів, ймовірність банкрутства, точка беззбитковості [5, с. 21]. На нашу думку, така методика має певні недоліки у використанні, а саме: 1) викликає сумнів саме такий набір коефіцієнтів через їх значну різноплановість; 2) такі показники, як швидкість обороту товарних запасів і точка беззбитковості більш доцільно розраховувати у процесі управління прибутком і витратами підприємства як інструмента операційного левериджу; 3) викликає сумнів використання такого індикатора, як імовірність банкрутства суб'єкта господарювання, оскільки моделей для їх оцінки є безліч і всі вони мають свій набір показників. 3 огляду на вищезазначене, вважаємо, що використання такого методу для оцінювання стану фінансової безпеки корпоративних структур є недоцільно.

Л. Гнилицька рекомендує для оцінювання стану фінансово-економічної безпеки підприємства використовувати систему збалансованих індикаторів, які згруповує в такі напрями стратегічного розвитку, як: фінанси, клієнти, бізнес-процеси, кадровий потенціал [6, с. 264]. Така методика передбачає розгляд стану фінансової безпеки на основі дослідження основних показників його фінансово-господарської діяльності. Проте дослідження фінансової безпеки корпоративних структур із використанням таких індикаторів $€$ неможливим, оскільки їх сукупність не відображає всіх фінансових аспектів функціонування підприємства, а також немає обгрунтування на основі яких саме індикаторів оцінюють кожен із запропонованих автором блоків.

Аналогічні індикатори для оцінювання стану фінансової безпеки торговельного підприємства використовує також і М. О. Кокнаєва [7, с. 55], проте науковець пропонує досліджувати такі індикатори на предмет їх стимулювання або де стимулювання фінансово-економічної безпеки досліджуваного суб'єкта господарювання. Окрім цього, запропоновано таку модель оцінювання фінансово-економічної безпеки підприємства торгівлі на основі присвоєння ваги кожній групі бізнес-процесів через проведення експертного оцінювання:

$$
Y_{\Phi E S}=0,21 \times Y_{\mathrm{V}}+0,25 \times Y_{\Phi}+0,14 \times Y_{P}+0,13 \times Y_{T}
$$

де $Y_{y}$ - узагальнювальна оцінка організаційно-управлінських бізнес-процесів; $Y_{\Phi}$ - оцінка фінансовоаналітичних процесів на підприємстві; $Y_{P}$ - узагальнювальна оцінка ринкових бізнес-процесів підприємства; $Y_{T}$ - оцінка торговельних бізнес-процесів суб'єкта господарювання.

Як бачимо, запропонований підхід $є$ цікавим із погляду врахування різнобічних аспектів фінансово-господарської діяльності торговельних підприємств, проте не зовсім зрозумілими є критерії відбору індикаторів до кожної із груп узагальнювальної оцінки та методику обчислення вільних членів рівняння узагальнювальної оцінки фінансової безпеки суб'єктів господарювання.

М. О. Кокнаєва також пропонує здійснювати оцінку фінансової безпеки торговельних підприємств у такі чотири етапи: 1) визначення основних зовнішніх і внутрішніх факторів впливу на функціонування підприємств; 2) загальна оцінка фінансових результатів господарювання підприємства; 3) моделювання управлінських впливів на забезпечення фінансової безпеки підприємств торгівлі; 4) узагальнення отриманих результатів [7, с. 54].

Ю. Б. Кракос і Р. О. Разгон пропонують до складу таких індикаторів віднести: показники ефективності управління підприємством, платоспроможності, фінансової стійкості, ділової активності, ринкової стійкості та інвестиційної привабливості [8, с. 88-92]. Безумовно, такий підхід $\epsilon$ комплексний і всео- 
хоплювальним щодо руху фінансових ресурсів на підприємствах, проте його варто було б доповнити показниками ефективності дивідендної політики. Тільки після цього такий підхід буде ефективним для оцінювання стану фінансової безпеки корпоративних структур.

Серед усієї сукупності показників фінансового стану підприємства для оцінювання стану фінансової безпеки К. С. Горячева, О. А. Ареф’єва та Т. Б. Кузенко пропонують долучати лише такі індикатори: величина власного капіталу, обсяг оборотного капіталу, обсяг позикового капіталу, величина інвестиційних ресурсів, показники прибутковості, фінансової стійкості та платоспроможності [9, с. 57]. Проте автори не відображають граничних меж кожного із запропонованих індикаторів, а тому фактичні результати розрахунків зазначених показників не мають бази порівняння, що не дозволяє отримати реальний результат оцінки фінансової безпеки підприємницьких структур. Водночас, вважаємо, що така сукупність індикаторів дублює класичну оцінку фінансового стану підприємства, що є не зовсім коректним, оскільки поняття фінансового стану та фінансової безпеки є взаємодоповнюючими, але не ідентичними.

Схожого підходу дотримується вітчизняний науковець I. О. Бланк, який виокремлює такі групи аналітичних коефіцієнтів: показники оцінювання фінансової стійкості підприємства, показники рентабельності, індикатори платоспроможності суб'єкта господарювання, показники оборотності активів і капіталу [10, с. 121].

Ще одним представником індикаторного підходу оцінювання стану фінансової безпеки суб'єктів господарювання $є$ М. Бєндіков, яких до основних фінансових індикаторів відносить обсяг «портфелю» замовлень; фактичний та необхідний обсяги інвестиційних ресурсів; рівень інноваційної активності підприємства, рівень рентабельності виробництва; фондовіддачу; прострочену дебіторську та кредиторську заборгованість; частку забезпеченості власними джерелами фінансування [11, с. 25]. Своєю чергою, O. I. Почечун пропонує використовувати такі індикатори для оцінювання стану фінансової безпеки підприємств залізничного транспорту: коефіцієнт покриття, коефіцієнт автономії, рівень фінансового левериджу, коефіцієнт забезпеченості відсотків до сплати, рентабельність активів, рентабельність власного капіталу, середньозважена вартість капіталу, показник розвитку компанії, тимчасова структура кредитів, темп зростання прибутку та активів, оборотність дебіторської та кредиторської заборгованості [12, c. 214]. Позитивним аспектом у запропонованому підході є виокремлення такого показника, як середньозважена вартість капіталу, оскільки такий індикатор є результативним у досягненні корпоративними структурами фінансової безпеки та найбільшою мірою показує диверсифікацію джерел фінансування суб'єктів господарювання. Проте, викликає сумнів такий набір показників оцінювання фінансової безпеки, оскільки зазначені науковцем індикатори можна застосувати для підприємства будь-якої галузі господарської діяльності. Екстраполяція таких показників для використання у практиці акціонерних товариств у загальному можлива, проте також не виокремлює особливостей фінансових відносин суб'єктів корпоративного сектору економіки. Тому, вважаємо, гарантувати отримання достовірного результату стану фінансової безпеки акціонерних товариств на основі такої методики не можна.

Із метою усунення основного недоліку індикаторного підходу - ототожнення його із методиками оцінювання фінансового стану підприємства, В. Яструбецький пропонує всю сукупність індикаторів поділити на групи:

1) кількісні показники: показники майнового стану, показники ліквідності та платоспроможності, показники фінансової стійкості, індикатори прибутковості, показники ділової активності, показники грошових потоків;

2) якісні показники: рівень корпоративної культури, рівень технічного захисту фінансової інформації, динаміка кількості перевірок із боку державних органів, наявність значної кількості міноритарних акціонерів, корпоративні конфлікти, рівень компетентності фінансових менеджерів, наявність фактів рейдерських атак, наявність простроченої кредиторської заборгованості, наявність фактів фінансових зловживань працівниками підприємства [13, с. 432].

Водночас науковець уважає, що якісні показники доцільно визначати експертним шляхом у балах, а за результатами аналізу визначає такі рівні фінансової безпеки підприємницьких структур: 1) високий $\rightarrow$ фінансові індикатори знаходяться в допустимих діапазонах, а якісні показники відповідають заявленим вимогам; 2) середній $\rightarrow$ значення лише одного індикатора не відповідає пороговому, а значення якісних показників не відповідають встановленим вимогам; 3) низький $\rightarrow$ значення переважної більшості фінансових індикаторів не відповідають граничним межам, а за якісні показники набувають загрозливих ознак [13, с. 431-432].

Така методика, на нашу думку, є суттєво доповненою, порівняно з іншими підходами науковців, особливо в частині виокремлення якісних індикаторів фінансової безпеки підприємств. Можемо погодитися 3 автором із таким поділом, особливо в частині тих показників, які відображають корпоративні відносини на підприємстві. Це означає, що така методика придатна до застосування саме на підприємствах акціонерної форми власності. Разом із тим підхід В. Яструбецького до оцінювання стану фінансової безпеки підприємств має декілька спірних аспектів. По-перше, вважаємо, що застосування експертного 
методу до оцінювання якісних показників фінансової безпеки за умов включення до експертної комісії суб'єктів фінансової безпеки досліджуваного підприємства буде мати суб' єктивний характер, що знижує якість оцінювання стану фінансової безпеки суб'єкта господарювання. Не зрозумілим є також які саме встановлюються вимоги до якісних показників оцінювання стану фінансової безпеки підприємств. Подруге, нечіткими є встановлені зони фінансової безпеки підприємства. По-третє, автором не відображено конкретного переліку індикаторів, а також їх порогових значень, що утруднить процес порівняння фактичних індикаторів із рекомендованими.

Ми вважаємо, що застосування індикаторного методу у практику оцінювання стану фінансової безпеки акціонерних товариств має такі переваги та недоліки (рис. 1):

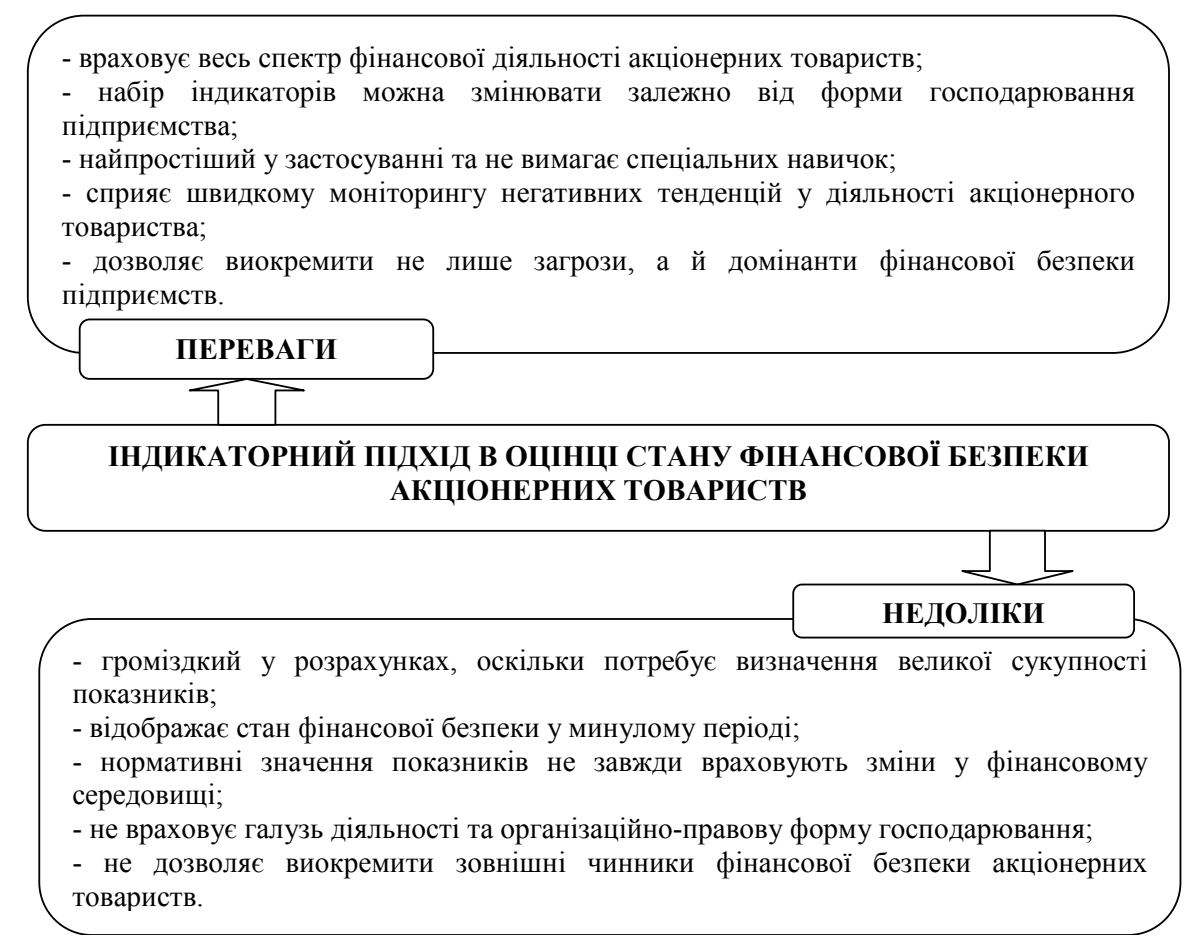

Рис. 1. Преваги та недоліки застосування індикаторного методу в оцінюванні стану фінансової безпеки акціонерних товариств*

*Складено автором.

Висновки. Отже, критичний аналіз індикаторного підходу до оцінювання стану фінансової безпеки підприємств дозволяє стверджувати, що такий підхід має окремі неточності. Вважаємо, що застосування індикаторного методу до оцінювання стану фінансової безпеки корпоративних структур є можливим за умови врахування індикаторів фондової активності суб'єктів господарювання, визначення порогових їх значень в залежності від галузі діяльності акціонерного товариства, а також, якщо відібрані індикатори будуть відповідати вимогам, серед яких: доступність до трактування й обчислення; можливість їх ранжування на діапазони за станом фінансової безпеки акціонерного товариства; вимога бути найбільш релевантними для визначення стану фінансової безпеки корпоративних структур; використання для обчислення реальної звітної інформації; оперативність розрахунку та виявлення загроз; системність у відборі показників і відображення всіх аспектів фінансової діяльності акціонерного товариства; можливість прослідковування тенденцій стану фінансової безпеки підприємств; придатність використання їх як бази для прогнозування майбутнього стану фінансової безпеки.

\section{Література:}

1. Косевцов В. О., Бінько І. Ф. Національна безпека України: проблеми та шляхи реалізації пріоритетних національних інтересів, Київ, НІСД, 1996. 260 с.

2. Шлемко В. Т. Економічна безпека України: сутність і напрямки забезпечення: монографія / В. Т. Шлемко, І. Ф. Бінько, Київ, НІСД, 1997. 144 с.

3. Козаченко Г. В. Економічна безпека підприємства: сутність та механізм забезпечення : [монографія] / Г. В. Козаченко, В. П. Пономарьов, О. М. Ляшенко, Київ, Лібра, 2003. 250 с.

4. Мороз О. В., Карачина Н. П., Шиян А. А. М80 Концепція економічної безпеки сучасного підприємства : монографія / О. В. Мороз, Н. П. Карачина, А.А. Шиян, Вінниця, ВНТУ, 2010. 259 с. 
5. Зарубинский В. М., Зарубинская Н. С. Финансовое управление предприятием на основе использования открытой информации. Актуальні проблеми економіки. 2003. № 3. С. 12-19.

6. Гнилицька Л.В. Використання концептуальних основ збалансованої системи економічних показників для оцінки стану та рівня економічної безпеки суб'єктів господарської діяльності. Фінанси, облік $i$ aудит. 2011. № 18. С. 263-271.

7. Кокнаєва М. О. Особливості формування методичного інструментарію дослідження фінансово-економічної безпеки торговельних підприємств. Економічний часопис - XXI. 2012. № 5-6. С. 53-55.

8. Кракос Ю. Б., Разгон Р. О. Управління фінансовою безпекою підприємств. Економіка та управління підприємствами машинобудівної галузі: проблеми теорії та практики. 2008. № 1 (1). С. 86-97.

9. Горячева К.С. Інформаціно-аналітичне забезпечення фінансової безпеки підприємства . Актуальні проблеми економіки. 2003. № 9. С. 16-21.

10. Бланк И. А. Управление финансовой безопасностью. Киев. «Ника-центр». Эльга. 2004.784 с.

11. Бендиков М. А. Экономическая безопасность промышленного предприятия в услови- ях кризисного развития. Менеджмент в России и за рубежом. 2000. № 2. С. 17-29.

Почечун О.І. Проблеми методики оцінки стану і рівня системи фінансової безпеки підприємств залізничного транспорту. URL: http://eadnurt.diit.edu.ua/jspui/bitstream/123456789/1611/1/703poche.pdf (дата звернення 25.03.2018).

Яструбецький В. Аналіз рівня фінансової безпеки суб’єктів господарювання. Економічний аналіз. 2012. Випуск 10. Частина 4. С. 430-433. 